\title{
The Ecology of Saprolegniaceae in Lentic and Littoral Muds with a General Theory of Fungi in the Lake Ecosystem
}

\author{
By M. W. DICK \\ Department of Botany, University of Reading, London Road, Reading, RGI $5 A Q$
}

(Accepted for publication II January I97I)

\begin{abstract}
SUMMARY
The occurrence and distribution of Saprolegniaceae in and around Marion Lake, British Columbia, Canada, has been investigated by single-core samples and transects in order to determine the principal sites of activity of these fungi. The lentic muds under $\mathrm{I} \mathrm{m}$. or more of water are generally very poor both in number of species and abundance. The marginal lentic muds are richer but reflect the flora of the emergent littoral muds. It is probable that many of the lentic mud records are for alien spores originating either from the open water community or the emergent littoral flora. These findings are discussed in relation to a general theory of fungi in the lake ecosystem. The majority of Saprolegniaceae are to be regarded as fungi of the emergent littoral. The distinctive acidophile community has again been recognized.
\end{abstract}

\section{INTRODUCTION}

Marion Lake, about $50 \mathrm{~km}$. east of Vancouver, British Columbia, has been selected by the Canadian International Biological Programme as a site for extensive and intensive ecological study of its entire biota. The topography and environment of the lake has been adequately described by Efford (1967).

This paper describes the distribution of Saprolegniaceae in and around the lake, including some notes on other Oomycetes. Although general statements (Willoughby, 1965; Dick, I968; Sparrow, 1968) have questioned whether the Saprolegniaceae are primarily submerged aquatic fungi, there have been no comparative accounts of the relative abundance or the distribution of species of Saprolegniaceae between the littoral and lentic environments. Without this information it is not possible to evaluate the evidence for particular sites of activity by these fungi, their principal natural substrates and their role in the general productivity of the lake ecosystem.

\section{METHODS}

The sampling method of Dick (1966) has been the standard method of treating samples throughout this study. About $50 \mathrm{~g}$. of litter and soil or mud was collected from each site and thoroughly mixed before Io replicate samples of about $5 \mathrm{~g}$. or $10 \mathrm{ml}$. were plated out and baited with hemp seed. The bottom muds were collected using the Hargrave sampler (Hargrave, 1969). The supernatant water was drained off before collecting the surface layer of bottom mud. Ten replicate plates of about io $\mathrm{ml}$. of mud were prepared from each sample. All plating out was done within $3 \mathrm{~h}$. of collection. Several attempts to use my method for estimating propagule numbers were 
Table I. Occurrence and abundance of species of Saprolegniaceae in the emergent, acidophile and submerged sites

24 Emergent sites

\begin{tabular}{|c|}
\hline $\begin{array}{l}\text { Number of } \\
\text { sites with } \\
\text { species }\end{array}$ \\
\hline
\end{tabular}

Achlya papillosa

Ach. inflata agg.

Saprolegnia litoralis

Ach. colorata

Sap. ferax

Ach. racemosa

Saprolegnia, non-sexual

Sap. diclina

Ach. megasperma

Ach. sparrowi

Sap. turfosa

Aphanomyces laevis

Aph. stellatus

Pythiopsis cymosa

Isoachlya monilifera

Achlya sp.

Ach. treleaseana

Scoliolegnia asterophora agg.

Sap. terrestris

Ach. americana

Scol. depauperata

Iso. unispora

Unidentified Saprolegniaceae

Leptomitus lacteus

Pythium undulatum

Pythium subgenus pythium

Pythium subgenus

nematosporangium

Pythiogeton sp.
I I Acidophile sites

$\overbrace{\begin{array}{c}\text { Number of } \\ \text { sites with } \\ \text { species }\end{array}}^{\begin{array}{c}\text { Mean number } \\ \text { of replicates }\end{array}}$

32 Submerged sites

$\overbrace{\begin{array}{c}\text { Number of } \\ \text { sites with } \\ \text { species }\end{array}}^{\begin{array}{c}\text { Mean number } \\ \text { of replicates }\end{array}}$

Total: 67 sites

$\begin{array}{cc}\begin{array}{c}\text { Number of } \\ \text { sites with } \\ \text { species }\end{array} & \begin{array}{c}\text { Number of } \\ \text { times recorded } \\ \text { (total 670) }\end{array}\end{array}$

$\begin{array}{ccr}5 & 1 \cdot 8 & 0 \\ 7 & 2 \cdot 9 & 0 \\ 4 & 4 \cdot 8 & 0 \\ 3 & \mathrm{I} \cdot 7 & \mathrm{I} \\ 6 & 3 \cdot 3 & 2 \\ 5 & 4 \cdot 4 & \mathrm{I} \\ 6 & 4 \cdot 3 & \mathrm{I} \\ 3 & 4 \cdot 3 & 0 \\ 5 & 2 \cdot 6 & 0 \\ 3 & 2 \cdot 3 & 0 \\ 5 & 4 \cdot 4 & 0 \\ 0 & 0 & 7 \\ 3 & 3 \cdot 0 & 1 \\ 4 & 2 \cdot 3 & 2 \\ 2 & 1 \cdot 5 & \mathrm{I} \\ 3 & 1 \cdot 3 & 0 \\ 2 & \mathrm{I} \cdot 0 & 0 \\ 0 & 0 & 1 \\ 0 & 0 & 3 \\ \mathrm{I} & 4 \cdot 0 & 2 \\ \mathrm{I} & \mathrm{I} \cdot 0 & 0 \\ 0 & 0 & 0 \\ \mathrm{I} & \mathrm{I} \cdot 0 & 0 \\ 2 & \mathrm{I} \cdot 0 & \mathrm{I} \\ 0 & 0 & 0 \\ 3 & \mathrm{I} \cdot 7 & 0 \\ 4 & 2 \cdot 0 & 0 \\ 4 & 1 \cdot 5 & 0 \\ 2 & 1 \cdot 0 & \end{array}$

0
0
0
$4 \cdot 8$
$2 \cdot 0$
$1 \cdot 0$
$I \cdot 0$
0
0
0
0
$3 \cdot 3$
$I \cdot 0$
$I \cdot 0$
$1 \cdot 0$
0
0
$8 \cdot 0$
$3 \cdot 3$
$I \cdot 0$
0
0
0
$I \cdot 0$
0
$1 \cdot 5$
0
0
0
0$$
2 \cdot 5
$$$$
26
$$$$
61
$$$$
67
$$$$
\begin{aligned}
& 2 \cdot 5 \\
& 3 \cdot 4
\end{aligned}
$$$$
\begin{aligned}
& 3 \cdot 4 \\
& 2 \cdot 0
\end{aligned}
$$$$
3 \cdot 3
$$$$
\begin{aligned}
& 3 \cdot 3 \\
& 3 \cdot 6 \\
& I \cdot 0
\end{aligned}
$$$$
\mathrm{I} \cdot \mathrm{O}
$$$$
\text { I. } 3
$$$$
4 \cdot 3
$$$$
\text { I. } 4
$$$$
\begin{gathered}
1.5 \\
0
\end{gathered}
$$$$
\text { I } 0
$$$$
\begin{gathered}
0 \\
1 \cdot 0
\end{gathered}
$$$$
\text { . }
$$$$
2 \cdot 0
$$$$
\begin{aligned}
& 2 \cdot 0 \\
& 5 \cdot 5
\end{aligned}
$$$$
0
$$$$
0
$$$$
\text { I. } 0
$$$$
\begin{gathered}
8 \cdot 5 \\
0
\end{gathered}
$$$$
\text { I } 0
$$$$
2 \cdot 0
$$$$
\begin{gathered}
0 \\
I \cdot O
\end{gathered}
$$$$
\text { I. } O
$$$$
23
$$$$
\begin{aligned}
& \text { I } 8 \\
& \text { I } 8
\end{aligned}
$$$$
\begin{aligned}
& \text { I } 8 \\
& \text { I6 }
\end{aligned}
$$$$
16
$$$$
\begin{aligned}
& \text { I } 4 \\
& \text { IO }
\end{aligned}
$$$$
\begin{array}{r}
10 \\
10
\end{array}
$$$$
\begin{aligned}
& 9 \\
& 8
\end{aligned}
$$$$
7
$$$$
\begin{aligned}
& 7 \\
& 7 \\
& 6
\end{aligned}
$$$$
\begin{aligned}
& 6 \\
& 5 \\
& 4 \\
& 4
\end{aligned}
$$$$
\begin{aligned}
& 4 \\
& 3
\end{aligned}
$$$$
\begin{aligned}
& 3 \\
& 3 \\
& 3
\end{aligned}
$$$$
\begin{aligned}
& 3 \\
& 3
\end{aligned}
$$$$
\begin{aligned}
& 3 \\
& 2 \\
& \text { I }
\end{aligned}
$$$$
\begin{aligned}
& \text { I } \\
& 5 \\
& 6
\end{aligned}
$$$$
\begin{aligned}
& 7 \\
& 8 \\
& 7
\end{aligned}
$$

0

0

0

o

2

బ 
made, but all gave such low counts that the results were deemed to be unreliable for both littoral and lentic samples. Contamination by a large number of Mucoraceous propagules also presented problems which could not be eliminated in the time available. Therefore, the measure of relative abundance was considered to be the most useful in this short-term investigation. Abundance is recorded as the number of replicates out of the ten possible, showing any growth of the particular species.

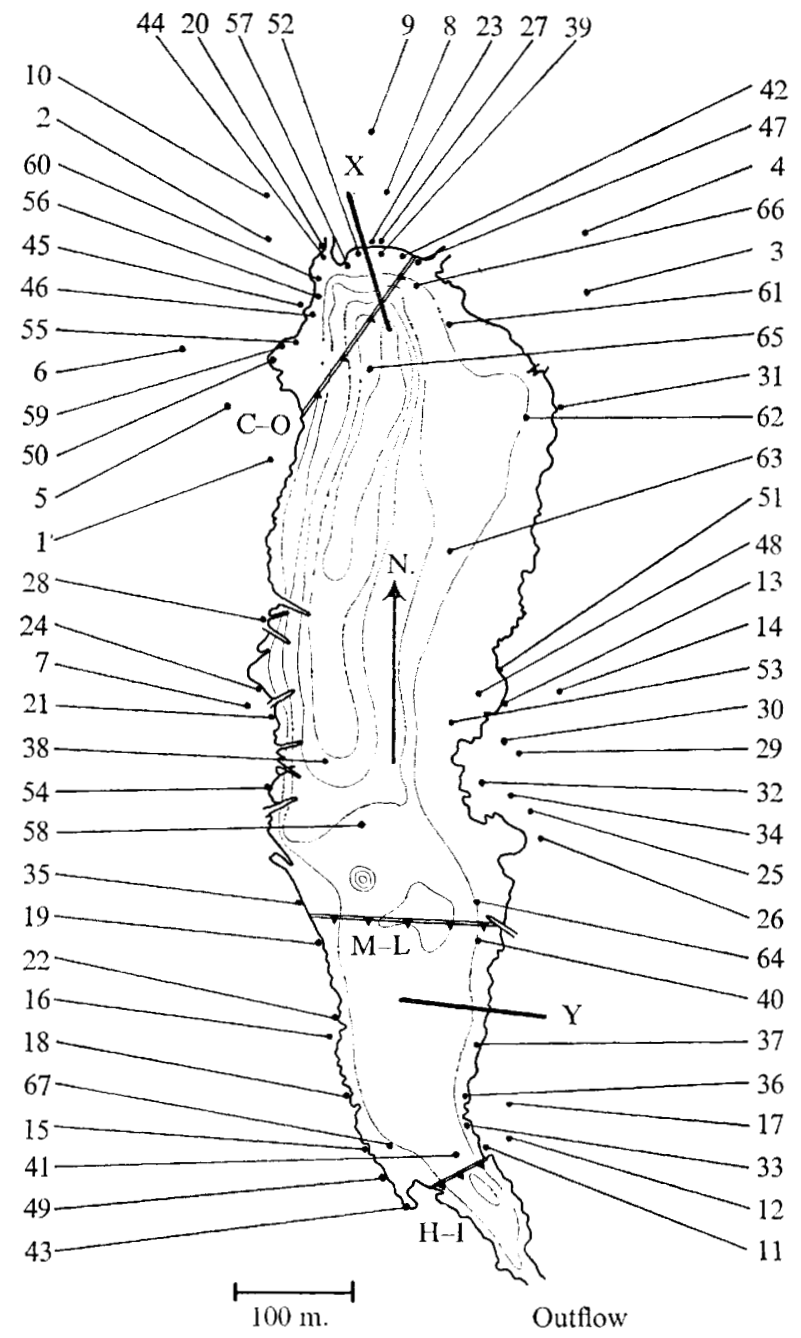

Fig. I. Map of Marion Lake showing sites of single-core samples and transects, and lake depth contours at $\mathrm{I} \mathrm{m}$. intervals.

\section{RESULTS AND COMMENTARY \\ General survey}

The cumulative data for the three principal groups of sites from single core samples taken between 2I February and 2 May 1969 are given in Table I. The actual sites are marked on the map (Fig. I) and are numbered in accordance with the table of cor- 
relations (Fig. 2). No site was revisited during this survey. Twenty-one species of Saprolegniaceae as well as non-sexual Achlya and Saprolegnia have been recorded from these samples. Leptomitus lacteus was the only representative of the Leptomitales found, although Sapromyces has been seen on submerged fruits (G. C. Hughes, personal communication). Pythium undulatum and at least two other species of Pythium

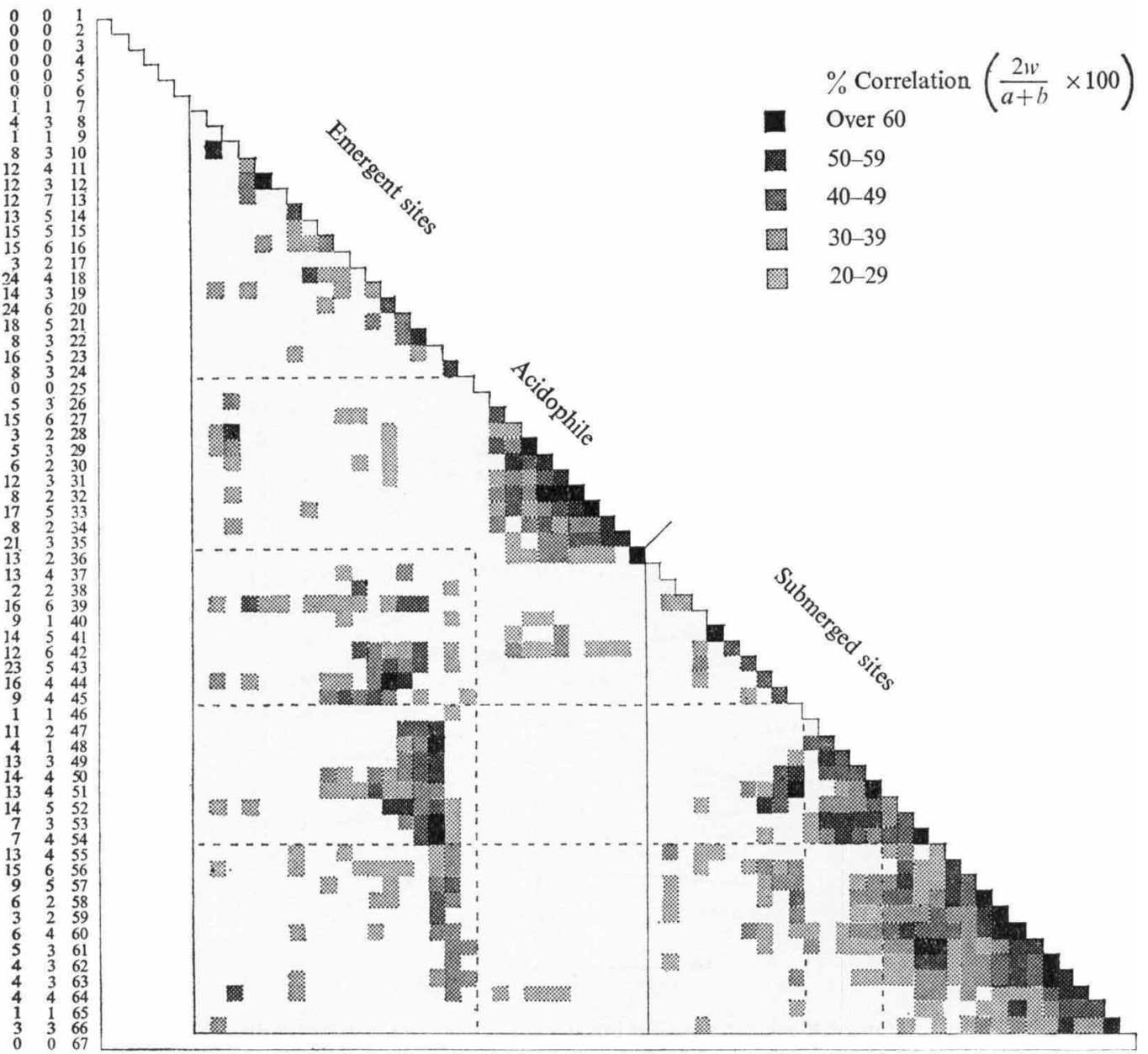

Fig. 2. Table of correlations between single-core samples.

were sometimes conspicuous, but since no special effort was made to isolate this genus it does not figure in the subsequent analysis, which is confined to the Saprolegniaceae.

The correlations between the sites (Fig. 2) have been computed according to the formula $2 w /(a+b) \times 100$ (Oosting, 1956) in which $w$ is the number of replicates common between $a$ and $b$, and $a$ and $b$ are the respective totals of replicates of all species 
recorded from the sites being compared. The mean value of $a+b$ in this study is approximately 20 . Thus either two species or two replicates for one species common between the two sites being assessed are likely to be required to give $20 \%$ correlation. The mean number of species per site was just over 3 . Correlation values of less than $20 \%$ have been discounted. In interpreting these data it must be remembered that since no site was revisited there is no measure of the sampling error or seasonal change. However, previous work (Dick, 1966) has shown relative abundance to be a reliable parameter at least for short periods of time. Relative abundance can lead to inflated levels of correlation, as can be seen from the figures for sites 9,46 and 65 , which had only one record for one species. On the other hand, the use of a formula which takes abundance into account is advisable in relation to the records for Saprolegnia litoralis and Achlya inflata which were usually recorded in several replicates. Thus it would be unwise to over-emphasize particular levels of correlation: any appreciable correlation is significant.

From a consideration of the data in Table 1 and Fig. 2 several groups of sites can be distinguished. The most distinct is that comprising sites 25 to 35 inclusive which are, by and large, wet sites from sphagnum or acid humus areas. Saprolegnia litoralis is characteristically abundant and is associated with Scoliolegnia asterophora or Sap. turfosa. Achlya treleaseana must be regarded as having an extremely narrow habitat range within this category. This distinct acidophile community has been noted previously (Dick, 1963). The drier terrestrial sites or wet sites further from the shore either lack Saprolegniaceae or show little correlation with each other and even less with any other group of sites. The remaining terrestrial and emergent littoral sites (many associated with the Myrica/Kalmia zone) again show low correlations amongst themselves, but as a group they show greater correlation with certain of the submerged sites. The submerged sites fall into three groups roughly characterized by: $(a)$ racemosagroup Achlya species plus Saprolegnia species but with few if any eccentric Achlya species (37 to 45 inclusive); (b) apiculata-group Achlya species (A. papillosa) plus eccentric Achlya species (A. inflata) and low counts for non-sexual Achlya, racemosagroup Achlya species and Saprolegnia species (46 to 54); and (c) dominant non-sexual Achlya ( 55 to 67 ). The first two groups are for the most part marginal submerged sites, while sites 55 to 67 are principally lentic deposits. Repeated sampling along selected transect lines was therefore carried out to confirm the impoverished nature of the saprolegniaceous flora of the bottom muds. Two shorter transects were also marked out and visited on four occasions to provide further data on the complex relationship between the emergent and submerged marginal sites.

\section{Transects across the lake}

The first series of transects, designed to study the lentic muds, comprised three transects across the lake sited near the inflow, two-thirds of the way down the lake and near the outlet. Five collections were made from each transect on 28 May, 5 July, 24 July, 4 September and 24 September 1969. The positive data proved to be so meagre that any discussion of seasonal effects was impossible. Negative samples were recorded most frequently in the third collection and least frequently in the first and fifth collections. Measures of abundance were erratic, suggesting either a large sampling error or a lack of homogeneity in the bottom muds. Table 2 gives the cumulative totals for each site from the five collections. In view of the apparent non-specificity between the 
Table 2. Transects across the lake: cumulative data for five collections at each site, ro replicates/site for each collection (a total of 600 plates)

\begin{tabular}{|c|c|c|c|c|c|}
\hline \multirow{2}{*}{$\begin{array}{l}\text { Transect } \\
\text { Lake Quadrat }\end{array}$} & \multicolumn{5}{|c|}{$\mathrm{C}-\mathrm{O}$} \\
\hline & 94 & 102 & 109 & I I 4 & $\begin{array}{l}\text { Mean \% } \\
\text { frequency }\end{array}$ \\
\hline Depth in metres & $>I$ & $>2$ & $>3$ & I & \\
\hline Negative samples & 25 & I9 & 34 & $3 I$ & $54 \cdot 5$ \\
\hline Achlya, non-sexual & 8 & 17 & 9 & 10 & $22 \cdot 0$ \\
\hline Leptolegnia caudata & 7 & 4 & I & 4 & $8 \cdot 0$ \\
\hline Saprolegnia, non-sexual & 4 & I & 2 & I & $4^{\circ} 0$ \\
\hline Saprolegnia diclina & 2 & 3 & I & $\mathbf{I}$ & $4 \cdot 5$ \\
\hline Aphanomyces laevis & I & 一 & 2 & - & $\mathrm{I} \cdot 5$ \\
\hline Achlya papillosa & 一 & 6 & 一 & 2 & \\
\hline Sap. litoralis & I & 一 & 一 & I & \\
\hline Ach. inflata & 一 & I & - & I & \\
\hline Leptomitus lacteus & I & I & 2 & - & \\
\hline Ach. colorata & 一 & 2 & - & 一 & \\
\hline Sap. terrestris & 一 & 一 & - & - & \\
\hline Aph. stellatus & - & - & - & - & \\
\hline Ach. apiculata & 一 & - & - & - & \\
\hline $\begin{array}{l}\text { Ach. sparrowit } \\
\text { Ach, racemosa }\end{array}$ & - & - & - & $\ldots$ & \\
\hline Ach. americana & - & I & - & - & \\
\hline Unidentified & I & - & - & — & \\
\hline
\end{tabular}

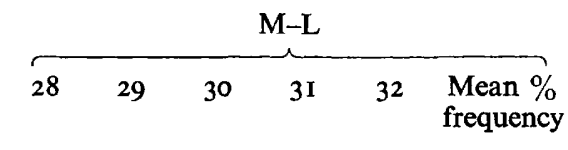

$\begin{array}{rrrrrr}<\text { I } & >\text { I } & >\text { 2 } & >\text { I } & \text { I } & \\ 2 \text { I } & 25 & 33 & 33 & 3 \text { I } & 57 \cdot 4 \\ 17 & 6 & 6 & 2 & \text { I } & 13 \cdot 2 \\ 2 & 9 & 7 & 8 & 2 & 12 \cdot 8 \\ 9 & 2 & 4 & \text { I } & \text { I } & 6 \cdot 8 \\ \text { I } & - & - & - & 7 & 3 \cdot 2 \\ \text { I } & \text { I } & - & \text { I } & \text { I } & 1 \cdot 6\end{array}$

All data:

mean \%

frequency

(principal

species)

$\begin{array}{rrr}<\text { I } & >\text { I } & <\text { I } \\ 27 & 25 & 37 \\ \text { I0 } & 7 & \text { I } \\ \text { I } & 9 & 6 \\ \text { I0 } & 2 & 5 \\ \text { I } & 2 & - \\ \text { I } & - & - \\ - & - & - \\ - & - & - \\ - & - & \text { I } \\ \text { I } & - & - \\ - & - & - \\ - & \text { I } & - \\ - & - & - \\ - & - & - \\ - & - & - \\ - & \text { I } & - \\ - & - & -\end{array}$

$56 \cdot 8$

I 6.0

10.6

IO. 3

$I \cdot 3$ 
Saprolegnia diclina group and the non-sexual Saprolegnia (Dick, 1970) these are considered together when discussing distribution patterns.

From Table 2 it can be seen that there are no well-marked trends or apparent differences between the three transects. This indicates that if inflow water movements influence the distribution of propagules in bottom mud, their effect is either limited to the immediate vicinity of the stream, and thus not affecting the lake bottom, or it is so strong as to scour the bottom and near margins more or less uniformly for the length of the lake.

From Table 3 it is clear that the depth of water overlying the bottom mud is probably immaterial to the distribution of propagules on the bottom mud.

Table 3. Transects across the lake: distribution of Saprolegniaceae with depth

Percentage of plates yielding principal species

Depth in metres

Negative samples Achlya, non-sexual Leptolegnia caudata $\left.\begin{array}{l}\text { Saprolegnia, non-sexual } \\ \text { Saprolegnia diclina }\end{array}\right\}$ Aphanomyces laevis

\section{at different depths}

\begin{tabular}{rrr}
\hline L I - I & $>\mathrm{I}-2$ & $>2-4$ \\
$58.8 \%$ & $54.0 \%$ & $57.3 \%$ \\
$\mathrm{I} 6.4 \%$ & $\mathrm{II} \cdot 5 \%$ & $2 \mathrm{I} \cdot 3 \%$ \\
$9.2 \%$ & $\mathrm{I} 6.5 \%$ & $8.0 \%$ \\
$\mathrm{I} 4.0 \%$ & $7.0 \%$ & $7.3 \%$ \\
$\mathrm{I} \cdot 2 \%$ & $\mathrm{I} \cdot 5 \%$ & $\mathrm{I} \cdot 3 \%$
\end{tabular}

\section{Transects across the littoral zone}

Two short transects $\mathrm{X}$ and $\mathrm{Y}$ were sited across the littoral zone at the north end and on the east shore (see Fig. I). Four collections were made at each site. The dates of the collections are given in Table 4.

From Table 4 and Fig. 3 and 4 it can be seen that there are several points of change along the short transects. The most obvious is the abrupt change in the abundance of propagules (as illustrated by the number of negative samples) between the submerged mud at the margin of the lake and the submerged muds one metre from the shore and beyond (Fig. 3). As would be expected, the total counts reciprocate with maximum numbers from the margin landwards.

The mean number of species per site expressed as a percentage of the total species recorded from that site has been used as an index of the homogeneity of the total counts from collection date to collection date at any one site. It can be seen from Fig. 3 that the lowest correlation occurs at site 7 . This could be a reflection of the large number of negative samples, but similarly high numbers of negative samples are shown in transect $\mathrm{X}$ at sites IO and II, and in Y at site I. In none of these, however, is this index as low.

Both transects show similar trends on the above analysis: both transects have many species in common and with broadly similar distributions (Table 4). Of the 24 taxa noted from the two transects, two species were found only in $\mathrm{X}$ and four species were found only in Y. Of all these only Achlya treleaseana and Scoliolegnia depauperata were recorded frequently. Therefore, in Fig. 4 the data from the two transects have been amalgamated. The largest number of species was recorded from sites 4 and 5 . 
Table 4. Occurrence and abundance of species of Saprolegniaceae in the $I 2$ sites of transects $X$ and $Y$

Sampling dates

Transect X: I6.9.69; I . 10.69; 15.10.69;29.10.69

Transect Y: $19.9 .69 ; 8.10 .69 ; 22.10 .69 ; 29.10 .69$

Notes on water level

In both transects the water level was highest at the time of the second collection and low by the time of the fourth collection.

Transect $X$. Site 5 was emergent only at the first collection, site 3 was reached by the water level only on the second collection, site 4 was then under $150 \mathrm{~mm}$. of water. Site 4 was emergent at the third and fourth collections.

Transect $Y$. Site 5 was not emergent during the collection period. Site 4 was emergent by $40 \mathrm{~mm}$. at the third collection. Site 3 was at water level on the second collection.

\begin{tabular}{|c|c|c|c|c|c|c|c|c|c|c|c|c|c|c|}
\hline \multirow[b]{2}{*}{ Species } & \multirow[b]{2}{*}{$\begin{array}{l}\text { Tran- } \\
\text { sect }\end{array}$} & \multicolumn{12}{|c|}{ Sites } & \multirow{2}{*}{$\begin{array}{c}\text { Number } \\
\text { of times } \\
\text { recorded } \\
\text { (total 960) }\end{array}$} \\
\hline & & I & 2 & 3 & 4 & 5 & 6 & 7 & 8 & 9 & IO & II & 12 & \\
\hline Saprolegnia diclina & $\begin{array}{l}X \\
Y\end{array}$ & 13 & 27 & 17 & $\begin{array}{l}17 \\
20\end{array}$ & $\begin{array}{r}14 \\
2\end{array}$ & $\begin{array}{l}7 \\
2\end{array}$ & $\begin{array}{l}4 \\
\mathrm{I}\end{array}$ & $\begin{array}{l}5 \\
3\end{array}$ & $\begin{array}{r}18 \\
2\end{array}$ & $\begin{array}{l}2 \\
\text { I }\end{array}$ & 4 & $\begin{array}{l}\text { I } \\
2\end{array}$ & 162 \\
\hline Achlya, non-sexual & $\begin{array}{l}X \\
Y\end{array}$ & $\stackrel{2}{-}$ & - & $\underline{2}$ & -4 & $\begin{array}{r}33 \\
\text { I }\end{array}$ & $\begin{array}{r}10 \\
3\end{array}$ & -3 & $\begin{array}{l}5 \\
6\end{array}$ & $\begin{array}{r}14 \\
4\end{array}$ & $\begin{array}{l}5 \\
4\end{array}$ & $\begin{array}{r}\text { II } \\
6\end{array}$ & $\begin{array}{r}19 \\
5\end{array}$ & 137 \\
\hline Sap. litoralis & $\begin{array}{l}X \\
Y\end{array}$ & $\overline{\text { II }}$ & $\begin{array}{r}1 \\
19\end{array}$ & $\begin{array}{l}\text { II } \\
35\end{array}$ & $\begin{array}{r}1 \\
23\end{array}$ & $\begin{array}{l}\text { I } \\
9\end{array}$ & $\overline{-}$ & I & - & -3 & - & $\overline{-}$ & - & II 5 \\
\hline Achlya sparrowii & $\begin{array}{l}X \\
Y\end{array}$ & 30 & $\begin{array}{r}2 \mathrm{I} \\
7\end{array}$ & $\underline{5}$ & $\frac{6}{-}$ & - & - & $\underline{\mathbf{I}}$ & $\stackrel{\mathbf{I}}{-}$ & - & - & - & - & $6 I$ \\
\hline Sap. terrestris & $\begin{array}{l}X \\
Y\end{array}$ & - & $\begin{array}{r}5 \\
13\end{array}$ & $\begin{array}{r}21 \\
6\end{array}$ & II & $\bar{I}$ & - & $\frac{\mathrm{I}}{-}$ & 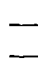 & - & - & - & - & 58 \\
\hline Leptolegnia caudata & $\begin{array}{l}X \\
Y\end{array}$ & - & - & - & $\overline{4}$ & I & $\begin{array}{l}5 \\
8\end{array}$ & $\begin{array}{l}\text { I } \\
2\end{array}$ & $\begin{array}{l}\text { I } \\
6\end{array}$ & $\begin{array}{l}3 \\
3\end{array}$ & $\begin{array}{l}2 \\
3\end{array}$ & - & - & 47 \\
\hline Saprolegnia, non-sexual & $\begin{array}{l}X \\
Y\end{array}$ & - & - & - & $\begin{array}{l}3 \\
4\end{array}$ & 4 & $\begin{array}{l}6 \\
\text { I }\end{array}$ & $\begin{array}{l}\text { I } \\
3\end{array}$ & -2 & I & $\overline{7}$ & $\begin{array}{l}2 \\
3\end{array}$ & $\begin{array}{l}2 \\
I\end{array}$ & $4 \mathrm{I}$ \\
\hline Aphanomyces stellatus & $\begin{array}{l}X \\
Y\end{array}$ & $\frac{7}{-}$ & $\begin{array}{l}4 \\
\text { I }\end{array}$ & $\underline{2}$ & $\underline{I}$ & - & - & $\begin{array}{l}\mathrm{Y} \\
\mathrm{I}\end{array}$ & $\begin{array}{l}6 \\
2\end{array}$ & $\bar{I}$ & $\begin{array}{l}2 \\
2\end{array}$ & $\overline{3}$ & - & 38 \\
\hline Ach. treleaseana & $\begin{array}{l}X \\
Y\end{array}$ & - & - & $\overline{-}$ & $\overline{2}$ & $\overline{32}$ & - & - & - & - & - & - & - & 34 \\
\hline Aphanomyces, non-sexual & $\begin{array}{l}X \\
Y\end{array}$ & $\underline{I}$ & - & $\stackrel{2}{-}$ & $\overline{-}$ & $\bar{I}$ & $\begin{array}{l}\mathbf{I} \\
\mathbf{2}\end{array}$ & $\bar{I}$ & $\begin{array}{l}2 \\
5\end{array}$ & $\overline{2}$ & $\overline{\mathrm{ro}}$ & - & $\overline{2}$ & 33 \\
\hline Scoliolegnia asterophora agg. & $\begin{array}{l}X \\
Y\end{array}$ & $\begin{array}{r}3 \\
\text { I0 }\end{array}$ & $\overline{9}$ & $\overline{\text { II }}$ & - & - & - & - & - & - & - & - & - & 33 \\
\hline Sap. ferax & $\begin{array}{l}X \\
Y\end{array}$ & - & - & $\underline{I}$ & 9 & $\begin{array}{l}\text { I } \\
\text { I }\end{array}$ & - & 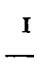 & $\begin{array}{l}\text { I } \\
2\end{array}$ & I & $\overline{-}$ & - & - & I7 \\
\hline Ach. papillosa & $\begin{array}{l}X \\
Y\end{array}$ & $2^{2}$ & - & $\underline{2}$ & 2 & - & $\begin{array}{l}\text { I } \\
\text { I }\end{array}$ & - & - & I & $\bar{I}$ & - & - & 14 \\
\hline Ach. colorata & $\begin{array}{l}X \\
Y\end{array}$ & - & - & - & $\frac{3}{-}$ & - & - & - & - & 二 & - & - & $\overline{3}$ & 13 \\
\hline Ach. racemosa & $\begin{array}{l}X \\
Y\end{array}$ & 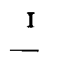 & - & - & 8 & - & $\bar{x}$ & - & - & - & $\bar{I}$ & - & $\underline{I}$ & 12 \\
\hline Ach. inflata & $\begin{array}{l}X \\
Y\end{array}$ & I & - & - & $\begin{array}{l}\text { I } \\
\text { I }\end{array}$ & $\begin{array}{l}2 \\
3\end{array}$ & - & - & $\overline{-}$ & - & $\overline{-}$ & - & - & II \\
\hline Scol. depauperata & $\begin{array}{l}X \\
Y\end{array}$ & $\overline{-}$ & - & $\overline{-}$ & - & 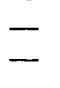 & - & - & $\overline{-}$ & $\overline{7}$ & - & $=$ & - & II \\
\hline Leptomitus lacteus & $\begin{array}{l}X \\
Y\end{array}$ & - & - & - & $\overline{-}$ & 4 & $\begin{array}{l}\mathbf{I} \\
\mathbf{I}\end{array}$ & - & $\bar{I}$ & - & $\bar{I}$ & - & $\begin{array}{l}\text { I } \\
\text { I }\end{array}$ & 10 \\
\hline
\end{tabular}


Table 4 (cont.)

Species

Aphan. laevis

Isoachlya unispora

Iso. monilifera

Ach. megasperma

Sap. turfosa

Iso. toruloides

Total count for

Saprolegniaceae

\begin{tabular}{|c|c|c|c|c|c|c|c|c|c|c|c|c|c|}
\hline \multirow{2}{*}{$\begin{array}{l}\text { Tran- } \\
\text { sect }\end{array}$} & \multicolumn{12}{|c|}{ Sites } & \multirow{2}{*}{$\begin{array}{l}\text { Number } \\
\text { of times } \\
\text { recordec } \\
\text { (total } 960\end{array}$} \\
\hline & I & 2 & 3 & 4 & 5 & 6 & 7 & 8 & 9 & 10 & I I & & \\
\hline$\underset{Y}{X}$ & - & - & - & - & $\underline{\mathbf{I}}$ & 3 & - & - & - & I & - & - & \\
\hline $\begin{array}{l}\mathrm{X} \\
\mathrm{Y}\end{array}$ & $\begin{array}{l}3 \\
2\end{array}$ & - & I & - & - & - & - & - & - & - & - & - & 6 \\
\hline $\begin{array}{l}X \\
Y\end{array}$ & I & $-\frac{1}{2}$ & - & - & - & $=$ & - & - & $\overline{\mathbf{I}}$ & - & - & 二 & 4 \\
\hline $\begin{array}{l}\mathrm{X} \\
\mathrm{Y}\end{array}$ & 3 & -- & - & - & - & - & - & - & - & 二 & - & - & 3 \\
\hline $\begin{array}{l}\mathrm{X} \\
\mathrm{Y}\end{array}$ & - & - & - & - & - & - & - & - & - & - & - & - & \\
\hline $\begin{array}{l}X \\
Y\end{array}$ & - & I & - & - & - & - & - & - & - & - & - & - & 1 \\
\hline $\begin{array}{l}X \\
Y\end{array}$ & $\begin{array}{l}67 \\
23\end{array}$ & $\begin{array}{l}59 \\
52\end{array}$ & $\begin{array}{l}64 \\
56\end{array}$ & $\begin{array}{l}62 \\
56\end{array}$ & $\begin{array}{l}59 \\
58\end{array}$ & $\begin{array}{l}33 \\
22\end{array}$ & $\begin{array}{l}16 \\
12\end{array}$ & $\begin{array}{l}24 \\
24\end{array}$ & $\begin{array}{l}4 \mathrm{I} \\
24\end{array}$ & $\begin{array}{l}12 \\
26\end{array}$ & $\begin{array}{l}17 \\
26\end{array}$ & $\begin{array}{l}24 \\
22\end{array}$ & \\
\hline
\end{tabular}

Percentage correlation between adjacent sites has been calculated at two levels, viz. qualitative (i.e. presence or absence) and quantitative (i.e. taking frequency into consideration, using the formula $2 w /(a+b) \times$ I00 (Oosting, 1956)). In the former, two

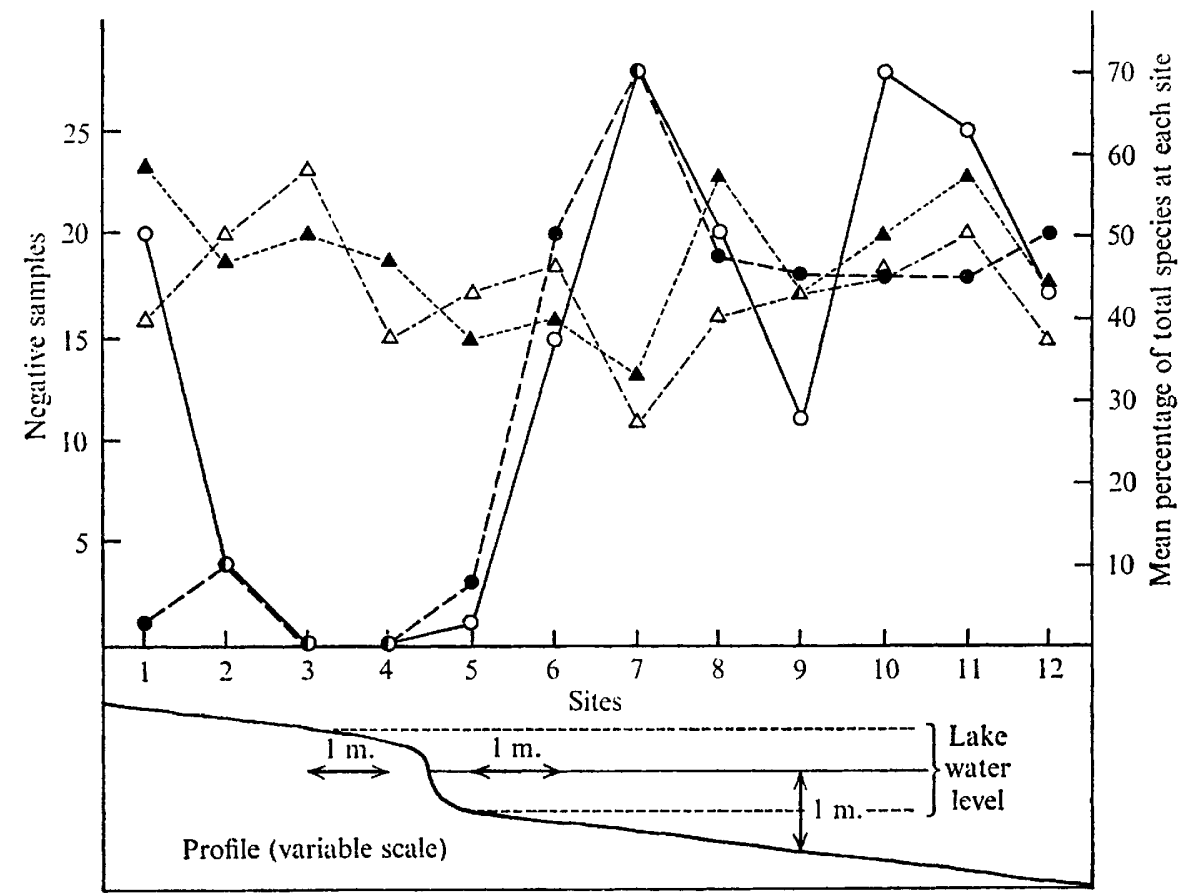

Fig. 3. Transects $X$ and $Y$ showing the numbers of negative samples and the mean percentages of the total number of species of Saprolegniaceae present at each site. $0-0$, Negative samples, transect $\mathrm{X} ; \bullet--\bullet$, negative samples, transect $\mathrm{Y} ; \Delta-\cdot-\Delta$, mean percentage of total species recorded at each site, transect $X ; \Delta-.-\Lambda$, mean percentage of total species recorded at each site, transect $Y$. 
troughs can be distinguished between sites 3 and 4 and 6 and 7. The latter shows a sharp decline between sites 3 and 4 followed by a gradual recovery from sites 5 and 6 .

Considering the data as a whole, two types of change can be seen: $(a)$ the change in total count and general abundance of saprolegniaceous propagules; $(b)$ breaks in the continuum of associations. The structure of the community changes between sites 3 and 4 as the spectrum of species widens. Associations are more diverse though some species are common throughout the terrestrial sites. Sites $I$ to 3 are characterized by

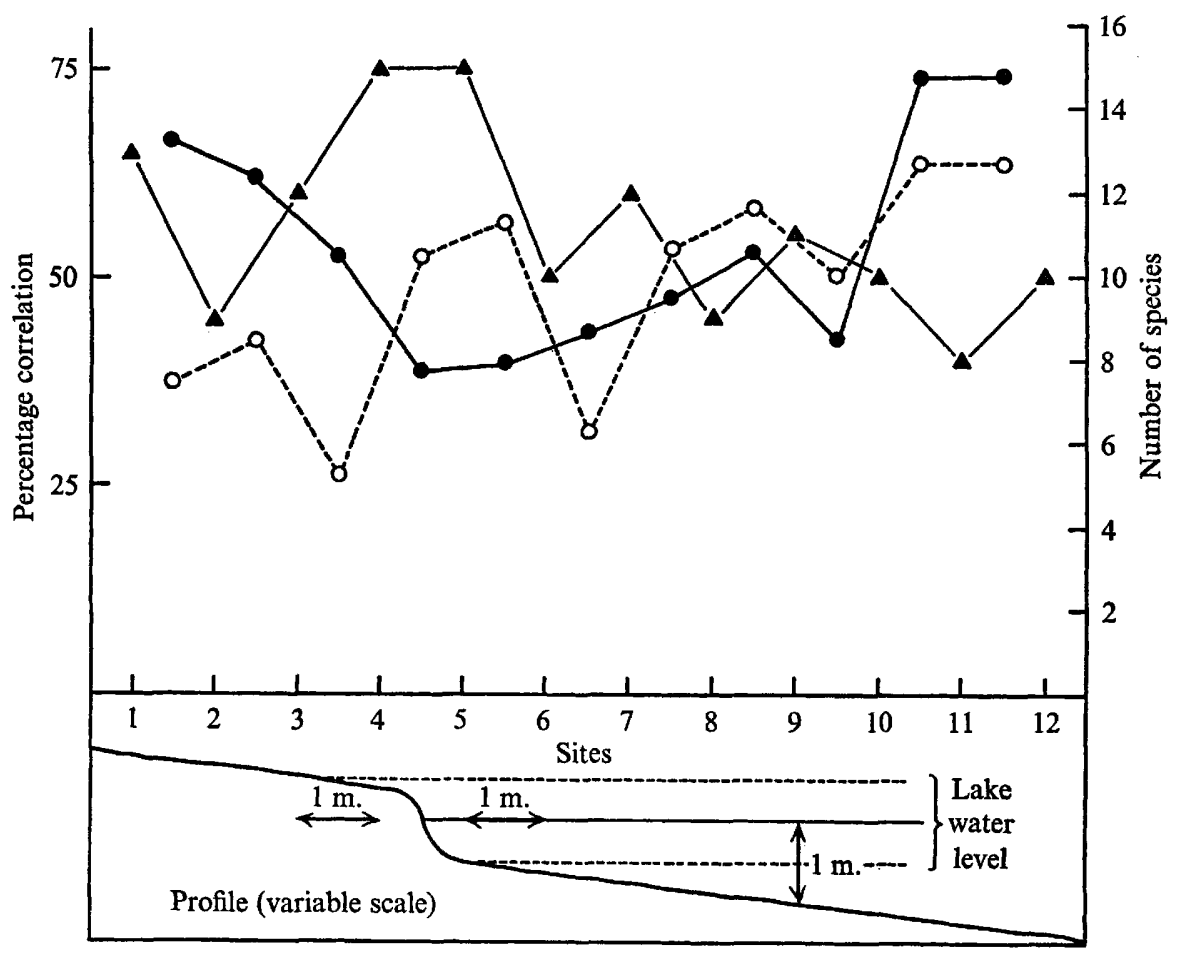

Fig. 4. Transects $X$ and $Y$ showing the numbers of species and the percentage correlations

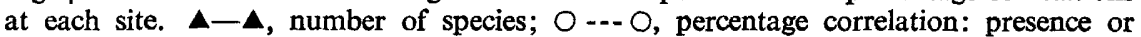
absence of species; - percentage correlation: abundance using the formula $2 w /(a+b) \times$ 100.

the association Saprolegnia litoralis, Sap. terrestris, Scoliolegnia asterophora and Achlya sparrowii. Isoachlya unispora may be a regular associate and Sap. diclina may be included under certain conditions. It is interesting to note that though occasionally flooded, site 3 appears to resemble the wet terrestrial sites rather than the littoral sites 4 and 5 .

The littoral association is characterized by the diversity of Achlya and Saprolegnia species. It is of interest to note that, as found in the general survey, this association continues from the emergent part of the bank to a distance of about a metre from the shore, but that between sites 5 and 6 a pronounced drop in density occurs. This suggests that the submerged marginal sites do not constitute a permanent reservoir of potential inoculum but rather a depository of outwash spores and sites of occasional 'alien' colonization. The exception would appear to be Achlya treleaseana, and it is 
worth recording that in contrast to the soft muds over most of the lake bottom site 5 of $Y$ was of firm silt with many roots of aquatic grasses and sedges.

The change in propagule density together with the low correlation from collection to collection and the low correlation with adjacent sites suggests that there is a major break in the continuum of associations beyond $\mathrm{I} \mathrm{m}$. from the shore and before the water depth attains I m. Only Leptolegnia caudata and Saprolegnia diclina appear to bridge this zone. In this connexion it is tempting to suggest that the infrequent occurrence of non-sexual Achlya at site 7 might mean that this taxonomic category may be of two components: the littoral, derived from species related to Achlya papillosa and $A$. inflata, and the lentic, composed of heterothallic species.

\section{(a) Results}

\section{DISCUSSION}

In spite of the different seasonal spans over which these series of samples were taken, the results from the transects support the conclusions drawn from the singlecore samples. The lake has a relatively uniform pattern of distribution in which the relationship of the site to the lake margin is of greater importance than the water table or water content at any given site. Two examples of possible seasonal effect are (i) the slightly different floristic results for lentic muds between the early samples and the later transect data, and (ii) the different relative levels of general abundance of propagules between the submerged and emergent marginal sites from the single-core samples and the transects $X$ and $Y$.

The first of these differences should be considered in relation to the data from insect exuviae (Dick, 1970). The same four taxa are most frequent in both the transects and the exuviae, but the order of abundance is very different. On insect exuviae Aphanomyces and Saprolegnia were most frequent, followed by Leptolegnia and Achlya. The low records for Aphanomyces from the transects may be explained by the different sampling techniques used (Dick, I966, I970) but the difference in the non-sexual Achlya records is unaccountable. In the single-core samples only the non-sexual Achlya was prominent.

Most of the single-core samples were taken under ice when insect emergence would be low. It is therefore probable that records for Aphanomyces laevis, Saprolegnia diclina agg. and Leptolegnia caudata from bottom mud really represent a 'fall-out' from an open-water summer flora. A high potential inoculum in the mud is not essential to this open-water association if it is truly seasonal and linked to exuviae substrates (Dick, I970). In this context these records may be grouped with the occasional isolates of a large number of other species probably representing viable but alien propagules redispersed by water from other habitats. The lentic association is thus composed of three components: that derived from exuviae, outwash aliens, and the non-sexual Achlya. Indeed, one could argue that although the bottom mud contains viable saprolegniaceous spores, there is little evidence for much, if any, biological activity by Saprolegniaceae in these lentic muds with the only possible exception being the non-sexual Achlya.

The exceptional prolonged ice cover to the lake in the early months of 1969 may also explain the high counts for marginal sites in the general survey, for turbulence and scouring by water flow would have been minimal for several months allowing accumulation of propagules. Thus the hypothesis that many of these propagules were outwash 
spores from the margin would still hold. Nevertheless, the apiculata-group Achlya species, the aplanes-group Achlya species, the eccentric Achlya species and several Saprolegnia species were sufficiently numerous to be regarded at least as active aliens and most probably actual inhabitants of the marginal lentic muds. However, since the interface between the submerged and emergent littoral is rarely static, the scouring action over soft muds must mean that the potential inoculum frequently comes from the emergent littoral muds.

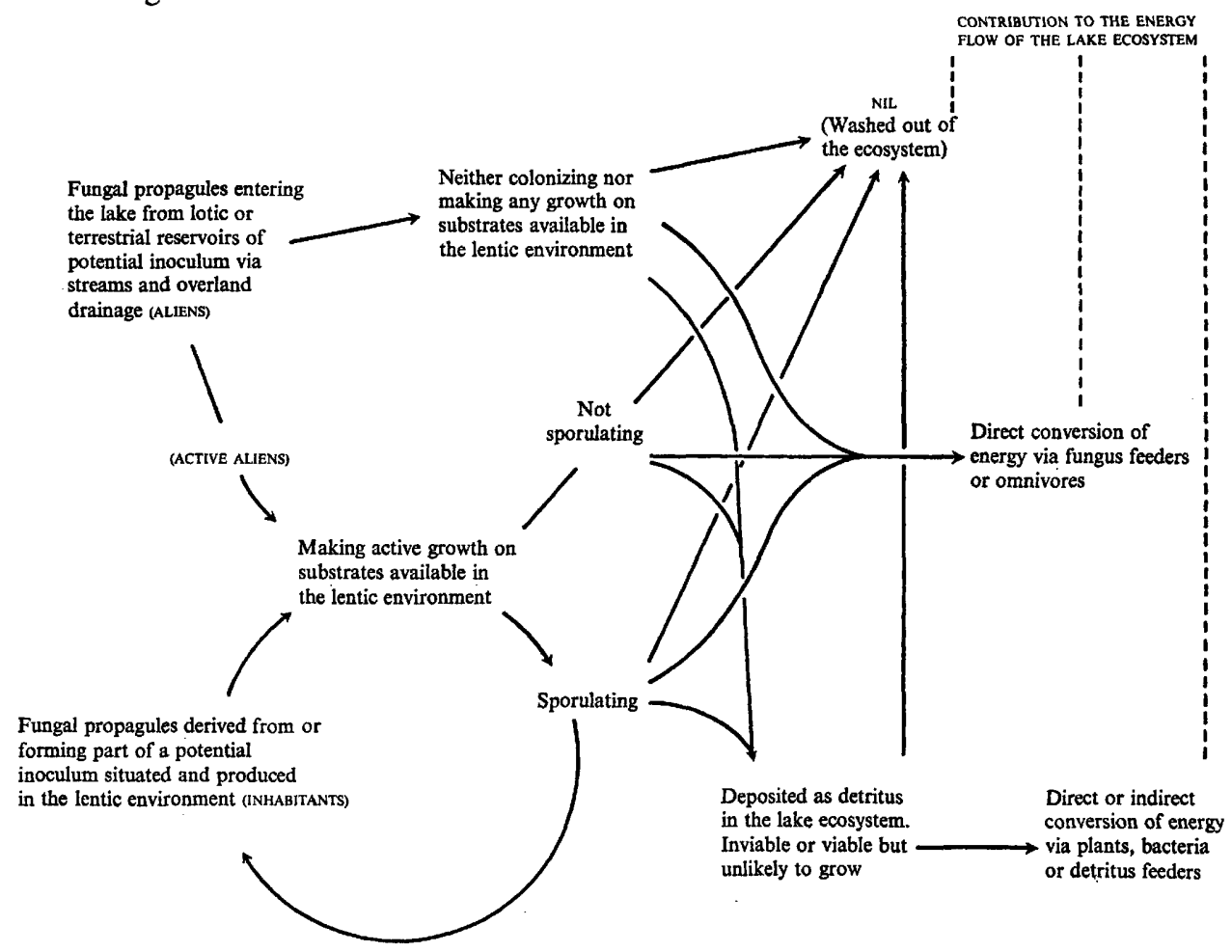

Fig. 5. Diagram of patterns of contribution of fungi and the energy flow in the lake ecosystem.

\section{(b) Fungi in the lake ecosystem}

When discussing the ecology of aquatic fungi in relation to their role in energy transfer in a lake ecosystem, it is important to distinguish between several different patterns of contribution. Since individual saprophytic fungi will colonize many suitable substrates under a range of environmental conditions, these patterns, which may be followed in Fig. 5, will correspond only approximately to specific or clonal identifications. There is a unidirectional flow through the system, and the maintenance of perennial reservoirs of potential inoculum within the ecosystem is not fully explained.

It can already be seen that species of Saprolegniaceae may follow different pathways (Fig. 5). Achlya sparrowii and Saprolegnia litoralis are more likely to be active aliens. Aphanomyces laevis, Saprolegnia diclina agg. and other Saprolegnia species, Leptolegnia caudata and non-sexual Achlya must be regarded as inhabitants of the lentic environment. At the same time it is necessary to distinguish different types of lentic environment in the same lake. Species of certain environments, such as those asso- 
ciated with insect exuviae, are more obviously involved in the pattern of energy flow than others. It now appears probable that most Saprolegniaceae are primarily fungi of the emergent littoral and lentic/littoral interface and very few are clearly lentic. Both groups contribute to the energy flow of the lake ecosystem: while the contribution of the few truly lentic inhabitants to the energy flow can now be assessed, assessment of the contribution from the other species may be much more difficult, and the actual contribution may well be less.

The way is now open for autecological studies together with a search for the natural substrates of particular species representative of the habitats defined here.

This work was made possible by the award of a Research Associateship of the University of British Columbia under the auspices of the Canadian International Biological Programme. The paper is C.C.I.B.P. no. 96.

\section{REFERENCES}

Dick, M. W. (1963). The occurrence and distribution of Saprolegniaceae in certain soils of south-east England. III. Distribution in relation to pH and water content. Journal of Ecology 51, 75-81.

Drck, M. W. (1966). The Saprolegniaceae of the environs of Blelham Tarn: Sampling techniques and the estimation of propagule numbers. Journal of General Microbiology 42, 257-282.

Dick, M. W. (1968). Considerations of the role of water on the taxonomy and ecology of the filamentous biflagellate fungi in littoral zones. Veröffentlichungen des Instituts für Meeresforschung in Bremerhaven, Sonderband 3, 27-38.

Dick, M. W. (1970). Saprolegniaceae on insect exuviae. Transactions of the British Mycological Society $55,449-458$.

EFFORD, I. E. (1967). Temporal and spatial differences in phytoplankton productivity in Marion Lake, British Columbia. Journal of the Fisheries Research Board of Canada 24, 2283-2307.

HARGRAVE, B. T. (I969). Epibenthic algal production and community respiration in the sediments of Marion Lake. Journal of the Fisheries Research Board of Canada 26, 2003-2026.

Oosting, H. J. (1956). The Study of Plant Communities: An Introduction to Plant Ecology. San Francisco, California: Freeman.

Sparrow, F. K. (1968). Ecology of freshwater fungi. In The Fungi an Advanced Treatise, vol. 3. The Fungal Population, pp. 41-93. London \& New York: Academic Press.

Willoughby, L. G. (1965). Some observations on the location of sites of fungal activity at Blelham Tarn. Hydrobiologia 25, 352-356. 